\title{
Relevansi Alasan Penolakan Umat Atas Risalah Kenabian Dengan Alasan Penolakan Masyarakat Atas Reformasi Hukum Keluarga Islam
}

\author{
Mohammad Fauzan Ni'ami \\ (UIN Sunan Kalijaga Yogyakarta, email:niamifauzan01@gmail.com)
}

\begin{abstract}
Abstrak:
Tulisan kali ini mengupas alasan penolakan masyarakat Pakistan, Afghanistan, dan Indonesia. Menggambarkan alasan penolakan masyarakat atas lahirnya reformasi hukum keluarga Islam, dengan didahului uraian historitas pro-kontra reformasi Hukum keluarga pada ketiga negara tersebut. Hasil tulisan ini menunjukan terdapat relevansi antara alasan penolakan umat atas risalah kenabian dengan alasan penolakan masyarakat atas reformasi hukum keluarga Islam. Relevansi yang ditemukan adalah keduanya menolak perubahan (ideas movement), dan hanya ingin mempertahankan nilai kemapanan. (This article explores the reasons for the people of Pakistan, Afghanistan, and Indonesia. The people's reasons for reforming Islamic family law explain the historical pros and cons of Drawing Family Law in the three countries. The results of this paper indicate a relevance between the reasons for rejecting the prophetic message and the reasons for the users of Islamic family law reform. The relevance found is that both resist change (idea movement) and only want to maintain established values.)
\end{abstract}

Kata Kunci:

Risalah Kenabian, Reformasi Hukum Keluarga, Relevansi

\section{Pendahuluan}

Pembaruan merupakan suatu keniscayan yang lahir akibat transformasi sosial. Dalam konteks hukum keluarga tujuan adanya reformasi hukum keluarga Islam secara umum dibagi menjadi tiga kategori, pertama untuk unifikasi hukum perkawinan, kedua untuk meningkatkan status perempuan, ketiga untuk merespon 
perkembangan zaman yang beralasan doktrin konvensional kurang mampu menjawab permasalah saat ini. ${ }^{1}$

Ditinjau dari sisi historisitas, respon masyarakat atas reformasi hukum keluarga Islam hampir terjadi di berbagai negara, seperti negara bagian asia pasifik dan asia selatan yang meliputi Afganistan, Bangladesh, Pakistan, dan Turki. ${ }^{2}$ Negara bagian timur tengah seperti Bahrain, ${ }^{3}$ Yordania. ${ }^{4}$ Lalu negara bagian Afrika seperti Mesir, ${ }^{5}$ dan juga negara bagian Asia Tenggara seperti Malaysia, 6 serta Indonesia.

Reformasi yang dibawa oleh para utusan Allah pun juga mendapatkan respon dari masyarakat sekitar, terlebih berupa penolakan terhadap risalah kenabian dalam konteks ini merujuk pada hukum pernikahan. Seperti contohnya penghapusan cara pernikahan yang diterapkan oleh masyarakat jahiliyah yaitu pernikahan alistibdhâ', al-rahth, al-râyah. ${ }^{7}$ Lalu menjadikan mahar sebagai hak perempuan yang dinikahi bukan lagi milik wali perempuan tersebut, ${ }^{8}$ serta adanya bagian waris terhadap perempuan yang sebelumnya tidak ada pada masyarakat jahiliyah. ${ }^{9}$

Adanya wacana reformasi hukum keluarga di dunia, menimbulkan pro dan kontra antara pihak-pihak yang bersangkutan. Perdebatan ini ditengarai kaum-kaum progresif yang menginginkan reformasi serta kaum konservatif yang menolak wacana tersebut. Bahkan perdebatan sengit antara ulama-ulama ini menyangkut metodologi ataupun substansi hukumnya. Hal demikian juga yang terjadi di negara Afganistan, Pakistan, dan Indonesia.

Mengangkat kajian alasan penolakan masyarakat atas hukum keluarga Islam dalam satu pembahasan yang holistik haruslah

1 Khoiruddin Nasution, Pengantar dan Pemikiran Hukum Keluarga (Perdata) Islam Indonesia, (Yogyakarta: Academia+Tazzafa, 2010), 40.

2 Ahmad Tholabi Kharlie, dkk, Kodifikasi Hukum Keluarga Islam Kontemporer (Pembaruan, pendekatan, dan Elastisitas Penerapan Hukum, (Jakarta: Kencana, 2020), 31.

${ }_{3}^{3}$ Ahmad Tholabi Kharlie, dkk, Kodifikasi Hukum Keluarga Islam., 103.

4 Ahmad Tholabi Kharlie, dkk, Kodifikasi Hukum Keluarga Islam., 118.

${ }^{5}$ Ahmad Tholabi Kharlie, dkk, Kodifikasi Hukum Keluarga Islam., 169.

${ }^{6}$ Ahmad Tholabi Kharlie, dkk, Kodifikasi Hukum Keluarga Islam., 200.

7 Tim Kementerian Perwakafan dan Urusan Keislaman, al-Mausû'ah al-Fiqhiyyah alKuwaitiyyah, (Dar al-Salasil: Kuwait, 1427 H), cet. 2, xxxxi, 326.

8 Abad Badruzzaman, "Potret Kaum Perempuan Pra-Islam Dalam Al-Qur'an" Jurnal QOF, Vol. 3, No. 2, (Juli, 2019), 101.

${ }^{9}$ Lihat QS. An-Nisa': 7 . 
menjadikan historiografi sebagai landasan untuk mengungkap fakta yang terjadi pada masyarakat negara Afganistan, Pakistan, dan Indonesia yang melakukan reformasi hukum keluarga. Meskipun demikian, tidak semua dokumen sejarah memuat tentang alasan kontradiktif terhadap reformasi hukum keluarga. Lebih banyak hanya berbicara tentang tahun periodesasi dan kausalitas munculnya reformasi.

Artikel ini mengupas alasan-alasan penolakan masyarakat pada beberapa negara muslim yaitu Afganistan, Pakistan, dan Indonesia. Sistematika tulisan didahului oleh latar belakang yang membicarakan banyaknya penolakan masyarakat atas reformasi hukum keluarga, kemudian dilanjutkan dengan mendeskripsikan secara umum alasan penolakan masyarakat terhadap lahirnya reformasi hukum keluarga Islam pada negara Afganistan, Pakistan, dan Indonesia dengan didahului uraian historitas pro-kontra reformasi hukum keluarga Islam di negara tersebut. Kemudian dilanjutkan dengan deskriptif alasan penolakan risalah kenabian, lalu disambung dengan alasan penolakan masyarakat terhadap reformasi hukum keluarga islam serta relevansinya terhadap penolakan risalah kenabian. Akhirnya, tulisan dipungkasi dengan kesimpulan di bagian penutup sebagai jawaban terhadap permasalahan yang dikaji.

\section{Metode Penelitian}

Metode yang digunakan adalah library research atau penelitian kepustakaan yaitu dengan cara memaparkan data-data diperoleh berbagai literatur yang memiliki keterkaitan dengan tema yang diteliti, seperti buku dan artikel yang membahas dan/atau hasil penelitian tentang alasan masyarakat menolak reformasi hukum keluarga serta penolakan risalah kenabian. Kemudian tulisan ini menggunakan deskriptif analitif, yaitu mendeskripsikan alasan penolakan umat terhadap risalah kenabian yang terdapat di dalam al-Qur'an serta hadis nabi, kemudian dianalisis alasan penolakan tersebut serta direlevansikan dengan alasan penolakan masyarakat Afganistan, Pakistan, dan Indonesia terhadap reformasi hukum keluarga Islam.

\section{Pro-kontra dalam Reformasi Hukum Keluarga Islam}

Seperti yang telah disinggung di awal, bahwa perdebatan atas refprmasi hukum keluarga Islam terjadi di hampir setiap negara- 
negara yang mayoritas muslim. Pada pembahasan ini dititik fokuskan pada pelbagai macam penolakan-penolakan yang dilakukan oleh masyarakat, baik sipil, lembaga pemerintah, ataupun masyarakat.

\section{Afganistan}

Afganistan merupakan negara yang penduduknya hampir 90 persen tinggal di wilayah pedesaan dan perkampungan terpencil yang masih mempercayai adanya keadilan didalam hukum adat. Penduduk yang beragama Islam suni memiliki presentase $74 \%$, kemudian Islam Syi'ah 25\% serta lainya hanya 1\%. Di Afganistan, mayoritas penduduknya merupakan pengikut mazhab Hanafi sehingga mazhab Hanafi secara umum mendominasi berbagai daerah di Afghanistan. ${ }^{10}$

Pertama kalinya kodifikasi hukum keluarga di Afhanistan pada tahun 1920 dengan tambahan yang cukup berpengaruh pada tahun 1961. Pada tahun 1970 Undang-undang perkawinan secara resmi diumumkan, yang meliputi beberapa aspek seperti pendaftaran perkawinan, serta ketentuan perceraian. Reformasi hukum keluarga, khususnya perkawinan di Afghanistan baru dimulai pada fase tahun 1971, yaitu dengan ditetapkannya Qanun-i Idzwaj sebagai peraturan yang mengatur masalah pernikahan. ${ }^{11}$

Lalu pada tahun 1977 hukum sipil Afganistan menggabungkan ketentuan hukum keluarga dengan beberapa ketentuan seperti aspek reformasi pada perkawinan anak, poligami, serta perceraian. Perlu diingat bahwasanya hukum yang paling dominan berlaku di Afganistan adalah aliran Imam Hanafi, tidak hanya itu hukum adat Inggris juga cukup berpengaruh serta kuatnya juga pola keislaman masyarakat Afganistan. ${ }^{12}$

Undang-undang sipil Afganistan tahun 1977 merupakan reformasi hukum keluarga yang sangat dipengaruhi oleh pembentukan peraturan hak-hak perempuan. Kontrol dari Partai Demokrasi Afganistan telah mengarahkan pada reformasi institusi

\footnotetext{
${ }^{10}$ Hasballah Toisuta, “Hukum Keluarga di Afghanistan”, Jurnal Tahkim, Vol. IX, No. 1, (Juni, 2013), 37

11 Atho' Mudzhar dan Khairuddin Nasution, Hukum Keluarga di Dunia Islam Modern, Studi Perbandingan UU Modern dari Kitab-kitab Fikih, (Jakarta : Ciputat Press, 2003), 139

12 Ahmad Tholabi Kharlie, dkk, Kodifikasi Hukum Keluarga Islam., 33-34
} 
secara radikal di Afganistan yang menyebabkan peningkatan hak dan kedudukan perempuan. ${ }^{13}$

Reformasi yang mendasarkan pada pemenuhan hak-hak perempuan dipandang oleh kelompok Islamis konsevatif sebagai dari campur tangan ideologi feminis dari barat. Upaya yang telah diperjuangkan oleh kelompok reformis dipandang kelompok Islamis sebagai perbuatan yang melegitimasi aturan hukum wadh'i serta perbuatan yang membantah al-Qur'an dan Hadis. Kelompok Islamis juga bahwa kelompok reformis sejatinya sudah dipengaruhi oleh pemikiran hukum barat. ${ }^{14}$

Sekalipun telah ditetapkan, masih terdapat masyarakat yang melanggar undang-undang tersebut, misalnya saja pada pasal 66 dan 77 Undang-undang Keluarga Afganistan telah menegaskan peranan laki-laki dan perempuan didalam perkawinan, pada praktiknya justru yang terjadi adalah keluarga merupakan institusi superior yang menentukan suatu perkawinan bagi anak-anak mereka, dengan pertimbangan kepentingan semata seperti perekonomian, serta kesukuan. Apabila pasangan tersebut keluar (offside) pada ketentuan keluarga maka pernikahan seperti ini tidak dianggap.

Di lain itu, pertukaran perkawinan masih terjadi di negara tersebut, padahal dalam banyak kasus pihak yang dirugikan adalah perempuan. ${ }^{15}$ Tidak berhenti disitu praktek diskriminasi sepeti pernikahan dibawah umur, serta praktek pembunuhan terhadap perempuan dengan alasan defensisasi kehormatan keluarga masih sering dilakukan. ${ }^{16}$

Pada tahun 2009, Rencana Undang-Undang yang sangat kontroversial, yaitu adanya izin terhadap suami yang membuat isterinya kelaparan dengan alasan menolak berhubungan seks telah ditetapkan secara legal. ${ }^{17}$ Akibatnya kontroversi tersebut banyak

13 Ahmad Tholabi Kharlie, dkk, Kodifikasi Hukum Keluarga Islam., 40

14 Ahmad Tholabi Kharlie, dkk, Kodifikasi Hukum Keluarga Islam., 41

${ }_{15}$ Ahmad Tholabi Kharlie, dkk, Kodifikasi Hukum Keluarga Islam., 36-37

16 VOA, PBB: Hak-Hak Perempuan Dilanggar di Afghanistan: https://www.voaindonesia.com/a/pbb-hak-hak-perempuan-dilanggar-diafghanistan-111638384/87095.html, (diakses pada 12 Maret 2021)

17 BBC Indonesia, Kontroversi UU di Afganistan: http://www.bbc.co.uk/indonesian/news/story/2009/08/printable/090816_afghan women.shtml, (diakses pada tanggal 12 Maret 2021). 
protes yang digaungkan oleh masyarakat sipil maupun aktivis, mereka menilai bahwa undang-undang baru lebih konservatif. ${ }^{18}$

\section{Pakistan}

Perbedaan tinjauan yang mencolok atas reformasi hukum keluarga Islam terlihat dalam perdebatan sengit mengenai lahirnya Ordonansi Hukum Keluarga Islam (Muslim's Family Laws Ordinance) di Pakistan pada tahun 1961. Komisi Perkawinan dan Hukum Keluarga dibentuk pada tahun 1955 yang terdiri dari orang dari kalangan pembaru dan hanya segelintir orang dari kubu ulama konservatif. Dasar adanya perdebatan dimulai ketika kelompok mayoritas pembaru mengajukan beberapa argumentasi tentang reformasi hukum Islam di bidang perkawinan yang ditentang keras oleh kelompok Islamis konservatif. ${ }^{19}$

Secara singkat alasan yang menjadi pangkal dasar pembentukan komisi ini adalah bahwa agama Islam yang dipeluk oleh setiap Muslim tidak perlu dipersoalkan, selama berbicara mengenai asas yang mendasar dan sikap yang inklusif, kita dapat mengatakan bahwa ajaran Islam itu bersifat holistik-komprehensif yang mencakup segala bentuk aspek kehidupan. Di satu sisi, dapat pula dikatakan bahwa hukum Islam benar-benar bersumber pada asas yang datang dari Allah swt. sebagaimana yang telah termaktub dalam Al-Qur'an dan Hadis. Agama inilah yang dinegasikan dalam kemerdekaan dan konstitusi negara Pakistan. ${ }^{20}$

Kelompok progresif memberikan argumentasi tentang perlunya melakukan reformasi hukum keluarga Islam. Adapun beberapa alasanya meliputi; Pertama, pentingnya reinterprestasi terhadap nash al-Qur'an, agar hukum yang ada relevan dengan perkembangan zaman. Kedua, bahwa dalam doktrin agama Islam tidak pernah mengajarkan secara eksplisit untuk dibentuknya negara

18 Kompas, UU Perkawinan Afganistan Timbulkan Pro-Kontra: https://travel.kompas.com/read/2009/04/15/17461321/sitemap.html, (diakses pada tanggal 12 Maret 2021).

19 Barmawi Arief, “Respon Masyarakat Terhadap Hukum Keluarga Islam”, Jurnal Hukumah, Vol. 01, No. 01, (Desember, 2017), 14

20 John L Esposito dan John J. Donohue, Islam dan Pembaharuan Ensiklopedi MasalahMasalah, (Jakarta: Rajawali Press, 1994), 370. 
teokrasi. Ketiga, pembentukan negara Pakistan adalah langkah revolusioner yang menuntut adanya reformasi di setiap aspek, mulai dari sistem pendidikannya, perombakan hukum (legal justice), dan juga sistem prosedural peradilan untuk menggapai kesejahteraan rakyat. ${ }^{21}$

Salah satu muatan Muslim's Family Laws Ordinance Pakistan 1961 yang menjadi perdebatan dan menimbulkan kontroversi adalah pasal 6 sub-section 1-5 yang membahas tentang aturan poligami yang berbunyi:

"(1) No man, during the subsistence of an existing marriage, shall except with the previous permission in writing of the Arbitration Council, contract another marriage, nor shall any such marriage contracted without such permission be registered under this Ordinance. (2) shall be submitted to the Chairman in the prescribed manner together with the prescribed fee, and shall state the reasons for the proposed marriage, and whether the consent of existing wife or wives has been obtained thereto."

Pasal tersebut setidaknya memuat tentang aturan poligami yang harus izin kepada arbritation council dan juga istri pertama dengan menyertakan alasan-alasan untuk poligami. ${ }^{22}$ Terlebih pada subsection 5 yang menyatakan jika tidak mendapat izin arbritation council akan dikenakan sanksi berupa pidana dan denda. ${ }^{23}$

"(5) Any man who contracts another marriage without the permission of the Arbitration Council shall__(a) pay immediately the entire amount of the dower, whether prompt or deferred, due to the existing wife or wives, which amount, if not so paid, shall be recoverable as arrears of land revenue; and (b) on conviction upon complaint be punishable with simple imprisonment which may extend to one year, or with fine which may extend to five thousand rupees, or with both."

Perdebatan ini ditengarai oleh kelompok progresif-inklusif dengan kelompok Islamis-konservatif. Kelompok progresif-inklusif menyandarkan argumentasi bahwa poligami merupakan suatu tindakan yang tidak dianjurkan bagi masyarakat awam dan juga tidak diperintahkan, karena pada dasarnya poligami merupakan tindakan khusus untuk nabi Muhammad saw. Disamping itu, argumen yang dikemukakan adalah poligami yang terjadi saat ini mengandung resiko yang besar terhadap tuntutan keadilan dan kebahagiaaan rumah

21 Barmawi Arief, Respon Masyarakat., 14-15

22 The Muslim Family Laws Ordinance Pakistan 1961, 4.

${ }^{23}$ The Muslim Family Laws Ordinance Pakistan 1961, 4. 
tangga. Oleh sebab itu seyogyanya poligami harus diberikan peraturan agar tidak terdapat penyelewengan yang dilakukan seseorang, dan juga terlebuh dahulu harus meminta ke Mahkamah Matrimonial. ${ }^{24}$

Pada kalangan Islamis konservatif menentang keras pernyataan kelompok progresif. Pertama kali yang disoroti adalah pembentukan komisi yang dipandang tidak adil, karena golongan progresif dinilai tidak mengetahui ajaran Islam secara mendalam. Selanjutnya Islamis konservatif menganggap perbuatan reformasi yang dilakukan oleh kelompok progresif sebagai bid'ah dhalalah, dan juga telah menyeleweng dari syariat Islam. ${ }^{25}$ Pada ranah poligami kelompok konservatif menilai bahwa kelompok progresif hanya menjiplak pandangan barat yang melarang poligami yang secara jelas ada dalam al-Qur'an, serta tindakan pelarangan poligami justru akan membuka kran baru munculnya pelacuran. ${ }^{26}$

Hal demikian juga terjadi pada pasal 5 Muslim's Family Laws Ordinance Pakistan 1961 mengenai registration of marriages (pendaftaran pernikahan). Muatan ini dipertentangkan diselewengkan karena faktanya banyak masyarakat tidak melaksanakan peraturan demikian, karena beranggapan pencatatan perkawinan tidak menjadi unsur yang penting dibandingkan dengan prosedur perkawinan menurut agama Islam. ${ }^{27}$

\section{Indonesia}

Pembaharuan hukum keluarga Islam dapat dilihat dengan lahirnya beberapa tuntutan dari sejumlah organisasi perempuan agar Indonesia mempunyai Undang-Undang untuk mengatur perkawinan sejak tahun 1928. Sebab dalam suatu pertemuan yang bernama KOWANI (Kongres Wanita Indonesia ) pada tahun 1928 dibahas berbagai ketimpangan yang terjadi pada pernikahan di Indonesia, seperti perkawinan yang terjadi pada anak dibawah umur, adanya

\footnotetext{
24 Barmawi Arief, Respon Masyarakat., 15

25 Barmawi Arief, Respon Masyarakat., 15

${ }^{26}$ Barmawi Arief, Respon Masyarakat., 16

27 Ahmad Tholabi Kharlie, dkk, Kodifikasi Hukum Keluarga Islam., 83
} 
kawin paksa, poligami, serta adanya talak yang dilakukan secara sewenang-wenang. ${ }^{28}$

Kemudian pada 13 Oktober 1929 berkumpul di Bandung dan membuat kesepakatan perihal larangan pemberlakuan praktek poligami. Selanjutnya bulan Juni 1931 di Jakarta, Kongres Isteri Sedar memperkuat larangan praktek poligami di Indonesia. Tetapi dikubu lain, adalah Sarekat Isteri jakarta memberikan respon negatif serta memprotes keputusan resolusi larangan poligami. ${ }^{29}$

Meskipun demikian, pemerintah Hindia Belanda merespon dengan memunculkan Ontwerp Ordonantie op de Ingeschreven Huwelijken (Rancangan Ordonasi Perkawinan Tercatat) pada bulan Juni tahun 1937 yang diantara isinya menganut prinsip monogami serta tidak boleh menjatuhkan talak di luar pengadilan. Namun rancangan ini mendapatkan respon penolakan keras dari kelompok muslim, yang diawali oleh Nahdhatul Ulama dan Partai Syarikat Islam Indonesia. Kemudian disusul pergerakan Islam lainya, termasuk berbagai organisasi perempuan yang menilai bahwa ordonansi yang dibuat oleh pemerintah Hindia Belanda menyalahi ajaran Islam. Karena terdapat pro-kontra mengenai isi ordinasi tersebut, maka pemerintah mencabut kembali aturan itu. ${ }^{30}$

Tahun 1950, pemerintah akhirnya merintis terbentuknya UU Perkawinan yang sebelumnya juga meresmikan UU No. 22 Tahun 1946 Tentang pencatatan nikah, talak, dan rujuk, tetapi hanya berlaku pada wilayah Madura dan Jawa. Akhirnya, pemerintah secara resmi membentuk Panitia Penyelidik Peraturan dan Hukum Perkawinan, Talak dan Rujuk dengan tugas untuk meneliti lebih jauh dan meninjau kembali semua aturan yang berkaitan dengan perkawinan serta menyusun RUU yang relevan dengan dinamika perkembangan masyarkat. ${ }^{31}$ Akan tetapi munculnya RUU ini membuat keretakan antara dua partai pendukung utama kabinet,yaitu Partai Nasional Indonesia dan Nahdhatul Ulama. Sekalipun dibentuk panitia ad hoc

\footnotetext{
28 Fitri Mulyawan, Kiki Yulinda, dan Dora Tiara, “Politik Hukum Dalam Bidang Hukum Keluarga Islam di Indonesia", Jurnal Ensiklopedia Social Review, Vol. 3 No. 2, (Juni, 2021), 115

${ }^{29}$ Nety Hermawati, “Respon Terhadap Hukum Perkawinan”, Jurnal Al-Mizan, Vol. 11 No. 1, (1 Juni, 2015), 35

${ }^{30}$ Nety Hermawati, Respon Terhadap Hukum Perkawinan., 36

31 Nety Hermawati, Respon Terhadap Hukum Perkawinan., 36
} 
yang anggotanya terdiri dari semua kalangan, tidak ditemukan kata mufakat dan titik keluar. ${ }^{32}$

Pada tanggal 31 Juli 1973 pemerintah dapat menyiapkan sebuah draf RUU Perkawinan yang baru, kemudian disampaikan kepada DPR. Isi draf tersebut tidak lain tujuan dibentuknya RUU tersebut, yaitu agar terciptanya kepastian hukum bagi masalah pernikahan, melindungi hak-hak wanita, serta menciptakan peraturan yang sesuai dengan perkembangan zaman. Tetapi dalam proses berikutnya juga tejadi respon negatif dari fraksi Persatuan Pembangunan, alasanya sama seperti fraksi yang tidak sependapat, yaitu bahwasanya ada beberapa poin yang berkontradiksi dengan ajaran agama Islam. ${ }^{33}$

Alasan lainya adalah karena RUU Perkawinan mengindikasikan pencabutan hukum perkawinan adat dan perkawinan Islam yang telah dianut oleh kebanyakan masyarakat Indonesia. Di antara kritik tersebut misalnya dilontarkan oleh Asma Sjahroni, wakil dari fraksi Persatuan Pembangunan, dia mengungkapan bahwa RUU Perkawinan menganulir hukum perkawinan adat Indonesia, dan hukum perkawinan dalam Islam. ${ }^{34}$

Respon negatif terhadap RUU di DPR tidak hanya muncul pada fraksi yang bersangkutan saja, melainkan juga dari perseorangan maupun organisasi. Disamping itu sejumlah demonstran yang turun dijalan mengutuk rancangan itu sebagai tindakan sekuler. Lebih dari itu pada tanggal 27 September 1973 telah terjadi keributan didalam gedung DPR yang dilakukan oleh para aktivis yang berasal dari kalangan mahasisws. ${ }^{35}$

Beberapa rancangan pasal yang dianggap mendapat kritik keras dari kaum Muslim Indonesia diantaranya adalah rancangan aturan pencatatan sebagai syarat sah pernikahan pasal 2 UU Perkawinan yang berbunyi:

32 M. Zamroni, Prinsip-Prinsip Hukum Pencatatan Perkawinan di Indonesia, (Surabaya: Media Sahabat Cendikia: 2018), 47

${ }^{33}$ Nafi' Mubarok, "Sejarah Hukum Perkawinan Islam di Indonesia”, Jurnal Al-Hukama, Vol. 02, No. 02, (Desember, 2012), 152

34 Nety Hermawati, Respon Terhadap Hukum Perkawinan., 38

35 Nety Hermawati, Respon Terhadap Hukum Perkawinan., 38 
“(1) Perkawinan adalah sah, apabila dilakukan menurut hukum masing-masing agamanya dan kepercayaannya itu. (2) Tiap-tiap perkawinan dicatat menurut peraturan perundang-undangan yang berlaku."

Kritikan dan penolakan juga terjadi pada poligami harus mendapat izin dari pengadilan (pasal 3, 4 dan 5), kemudian pembatasan usia minimal pernikahan yaitu 21 tahun untuk laki-laki dan 18 tahun untuk perempuan (pasal 6), perkawinan campuran (pasal 11), pertunangan (pasal 13), perceraian dengan izin pengadilan (pasal 40), dan pengangkatan anak (pasal 62). ${ }^{36}$

Dari Paparan di atas bahwa kecenderungan respon negatif dan penolakan terhadap reformasi hukum keluaga Islam lebih mendominasi, hal demikian sangat dipengaruhi setidaknya tiga alasan utama, yaitu; pertama, Reformasi hukum keluarga Islam berbeda dengan pandangan filosofis-sosiologis yang telah mengakar dan mendalam di masyarakat, karena pemikiran mereka telah terdoktrin oleh fikih konservatif seperti yang dianut oleh masyarakat Afganistan.

Kedua, Metodologi pembuatan reformasi hukum keluarga Islam tidak sesuai dengan ketentuan metode fikih klasik, seperti penolakan masyarakat Pakistan karena menilai golongan progresif tidak mengetahui ajaran Islam secara mendalam, dan juga telah menyeleweng dari syariat Islam karena banyak corak pikiran barat yang dibawa ke rencana perundangan tersebut

Ketiga, reformasi hukum Islam terdapat indikasi manganulir hukum adat dan Islam, hal demikian yang menjadi salah satu alasan masyarakat Indonesia menolak unifikasi pembaruan hukum keluarga seperti rencana aturan batas minimal boleh nikah, larangan poligami, pencatatan perkawinan, talak di luar pengadilan, dan lain-lain.

\section{Alasan Penolakan Terhadap Risalah Kenabian}

Telah menjadi kesepakatan bersama bahwasanya misi risalah kenabian adalah reformasi soial menuju masyarakat madani, risalah kenabian dalam keseluruh kisah para rasul digambarkan datang kepada masyarakat yang tengah mengalami krisis pandangan hidup (way of life), sehingga memerlukan suatu rekontruksi sosial. Misalnya saja kehadiran Nabi Nuh di lingkunganya untuk megentaskan politeisme dan ritualisme terhadap berhala-berhala yang dilakukan

${ }^{36}$ Nety Hermawati, Respon Terhadap Hukum Perkawinan., 38-39 
Relevansi Alasan Penolakan Umat Atas Risalah Kenabian Dengan Alasan Penolakan Masyarakat Atas Reformasi Hukum Keluarga Islam

oleh kaumnya (QS. Nuh: 23-24)37, kehadiran Nabi Hud pada kaum 'Aad (QS. Al-A'raf: 70-71)38, kehadiran Nabi Shaleh pada kaum Tsamud (QS. Asy-Syu'araa:141-152), dan juga kehadiran Nabi Muhammad pada kaum Quraisy. ${ }^{39}$

Hakikatnya para Nabi mengusung misi yang sama, hubungan risalah Nabi Muhammad dan risalah Nabi terdahulu berjalan atas prinsip yang sama, yaitu penegasan ( $\left.t a^{\prime} k i d\right)$ serta kesempurnaan (tatmim) ${ }^{40}$ Rasulullah bersabda:

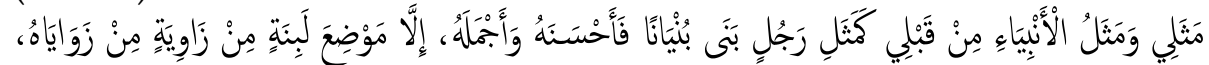

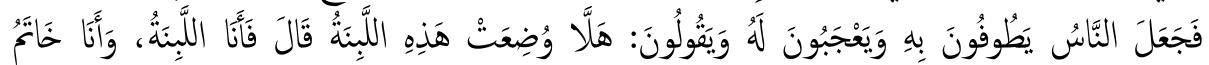
النَّبِّنَنَ.

"Perumpamaan aku dengan Nabi sebelumku ialah seperti seorang laki-laki yang membangun sebuah bangunan, kemudian ia memperindah dan mempercantik bangunan itu, kecuali satu tempat batu bata di salah satu sudutnya. Ketika orang-orang mengitarinya, mereka kagum dan berkata,

${ }^{37}$ QS. Nuh ayat 23-24:

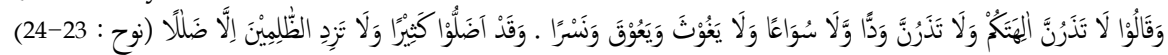

"Dan mereka berkata: "Jangan sekali-kali kamu meninggalkan (penyembahan) tuhan-tuhan kamu dan jangan pula sekali-kali kamu meninggalkan (penyembahan) wadd, dan jangan pula suwwa', yaghuts, ya'uq dan nasr". (23) "Dan sesudahnya mereka menyesatkan kebanyakan (manusia); dan janganlah Engkau tambahkan bagi orang-orang yang zalim itu selain kesesatan". (24)

38 QS. Al-A'raf 70-71:

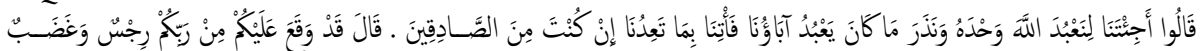

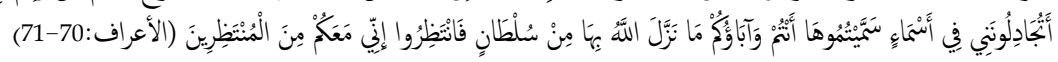

"Mereka berkata, "Apakah engkau (wahai Hud) datang kepada kami agar kami menyembah Allah semata dan meninggalkan apa yang biasa disembah oleh bapak-bapak kami? Maka, datangkanlah kepada kami apa yang kamu janjikan kepada kami jika kamu termasuk orangorang yang benar." (70) Dia (Hud) berkata, "Sungguh, sudah pasti kamu akan ditimpa azab dan kemarahan dari Tuhanmu. Apakah kamu sekalian hendak berbantah dengan Aku tentang nama-nama (berhala) yang kamu beserta nenek moyangmu menamakannya, padahal Allah tidak menurunkan sedikit pun hujah (alasan pembenaran) untuk itu? Maka, tunggulah (azab dan kemarahan itu)! Sesungguhnya aku bersamamu termasuk orang-orang yang menunggu." (71) ${ }^{39}$ Asep Dudi S, "Misi Risalah Islam Landasan Epistimologis Reformasi Sosial Menuju Masyarakat Madani", Makalah, LKTI Dosen Unisba Tahun 1999-2000, 91

${ }^{40}$ Muhammad Sa'id Ramadhan al-Buthi, Fiqh As-Sirah, Terj. Aunur Rafiq Shaleh Tahmid, (Jakarta: Robbani Press, 2002), 14

41 Abu Husain Muslim, Shahih Muslim, (Beirut: Darul Ihya' al-Kutub al-'Arabiyyah, $1431 \mathrm{H}), \mathrm{IV}, 1791$ 
"Tidaklah, jika batu bata ini diletakan? Akulah batu bata itu, dan aku adalah penutup para Nabi" (HR. Muslim)

Kedatangan risalah kenabian kepada para umat pada dasarnya membawa misi perubahan sosial pada tatanan yang lebih baik. Setidaknya misi risalah tersebut memuat delapan hal, yaitu: 1) Menjunjung tinggi supremasi hukum tuhan, 2) Membangun transendensi, 3) Menanamkan tauhidiyyah, 4) Rekontruksi tata nilai kehidupan, 5) Penataan aspek ritual dan segala aspek peribadatan, 6) Menegakan sikap adil dan egaliter, 7) Membebaskan dari belenggu kesesatan, 8) Mencerahkan dan mencerdaskan umat. 42

Tetapi pada kenyataanya penolakan terhadap risalah kenabian menjadikan problematika yang tidak kunjung usai. Penolakan risalah kenabian dapat dikelompokan berdasarkan historisitas para rasul, seperti Nabi Nuhdan Muhammad, dan juga masih banyak kisah penolakan masyarakat terhadap risalah kenabian.

Penolakan risalah Nabi Nuh yang dilakukan oleh kaumnya, dikarenakan risalah tersebut berisi tentang larangan menyembah selain Allah. Sementara alasan penolakan risalah tersebut karena masyarakat memandang Nabi Nuh sebagai manusia biasa yang tidak ada bedanya dengan manusia lainya, serta menganggap Nabi Nuh adalah orang gila (junun), hal demikian tertuang dalam surat al$\mathrm{Mu}^{\prime}$ min ayat 23-27.43

Demikian juga Nabi Ibrahim yang risalahnya ditolak mentahmentah oleh kaumnya, karena mereka menilai ajakan Nabi Ibrahim tidak berdasar dan menyimpang dari ajaran yang telah dianut oleh nenek moyang mereka, kisah ini tertuang pada surat al-Anbiya' ayat 52-57.

Penolakan keras juga terjadi pada risalah yang dibawakan oleh Nabi Luth tentang larangan untuk berbuat homoseksual, dalam kitab tafsir dijelaskan bahwasanya ketika Nabi Luth memerintahkan untuk menikahi perempuan yang suci maka mereka menolak mentah-

\footnotetext{
42 Asep Dudi S, “Misi Risalah Islam Landasan Epistimologis Reformasi Sosial Menuju Masyarakat Madani", makalah, 108

43 Khoiruddin Nasution, "Penolakan Umat Terhadap Risalah Kenabian Dan Relevansinya Dengan Penolakan Muslim Terhadap Undang-Undang Perkawinan", Jurnal ADHKI: Journal of Islamic Family Law, Vol. 2, No.2, (Juni, 2020), 29
} 
mentah dan lebih memilih menyetubuhi anus laki-laki. ${ }^{44}$ Cerita tersebut diabadikan dalam surat Hud ayat 77-79.45

Penolakan terhadap risalah yang dibawakan Nabi Syu'aib, yaitu tentang larangan untuk mengurangi takaran dan timbangan dagang serta anjuran untuk selalu berbuat keadilan. Alasan penolakan tersebut adalah karena masyarakat sudah menganggap praktek dagang yang telah mereka lakukan merupakan warisan turuntemurun dari nenek moyangnya, serta memandang Nabi Syu'aib adalah manusia yang rendahan kalau tidak karena keluarganya. Cerita ini termaktub dalam al-Qur' an surat Hud ayat 85-91.46

Hal demikian terjadi pada Nabi Muhammad saw., kaum kafir Quraisy bahkan dari pihak keluarga menolak apa yang telah Rasulullah sampaikan. Mereka berpaling dan menganggap bahwa Muhammad adalah orang gila. ${ }^{7}$ Terlebih lagi penolakan mereka disertai rencana untuk membunuh, membuang, dan mengasingkan Nabi Muhammad saw. karena dianggap mengganggu eksistensi agama nenek moyang mereka. ${ }^{48}$

44 Jalaluddin al-Mahalli, Jalaluddin Abdur Rahman al-Suyuti, Tafsir al-Jalalain, (Surabaya: Darul Jawahir, tt), 186

45 QS. Hud ayat 77-79:

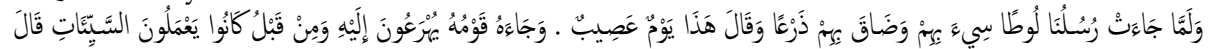

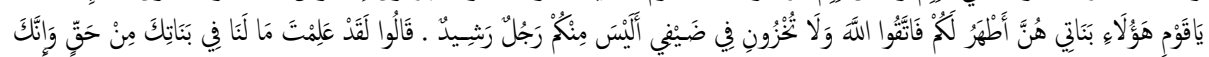

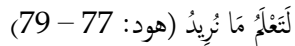

"Ketika para utusan Kami (malaikat) itu datang kepada Lut, dia merasa gundah dan dadanya terasa sempit karena (kedatangan) mereka. Dia (Lut) berkata, "Ini hari yang sangat sulit." (77) Kaumnya bergegas datang menemuinya. Sejak dahulu mereka selalu melakukan perbuatanperbuatan keji. Lut berkata, "Wahai kaumku, inilah putri-putri (negeri)-ku. Mereka lebih suci bagimu (untuk dinikahi). Maka, bertakwalah kepada Allah dan janganlah kamu mencemarkan (nama)-ku di hadapan tamuku ini. Tidak adakah di antaramu orang yang berakal sehat?" (78). "Mereka menjawab, "Sungguh, engkau pasti tahu bahwa kami tidak mempunyai keinginan (syahwat) terhadap putri-putrimu dan engkau tentu mengetahui apa yang (sebenarnya) kami inginkan." (79)

${ }^{46}$ Jalaluddin al-Mahalli, Jalaluddin Abdurrahman al-Suyuti, Tafsir al-Jalalain, 187

${ }^{47}$ QS. Al-Saffat ayat 36:

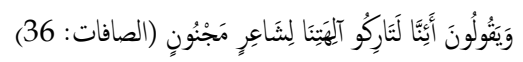

"Dan mereka berkata: "Apakah sesungguhnya kami harus meninggalkan sembahan-sembahan kami karena seorang penyair gila?"

48 Lihat Jalaluddin al-Mahalli, Jalaluddin Abdurrahman al-Suyuti, Tafsir al-Jalalain, 219 tafsir surat an-Nahl ayat 45 tentang konferensi kecil yang diadakan di pendopo Abu Jahal untuk membunuh, dan mengasingkan Nabi Muhammad saw. 
Inti yang tergambar diatas adalah bahwa alasan mereka menolak risalah kenabian karena bertentangan dengan tradisi yang telah mereka lakukan selama bertahun-tahun. Secara universal bisa kita ambil pola universal alasan masyarakat menolak risalah kenabian, yaitu; 1). Ketidakmauan masyarakat untuk mengalami berubahan, baik yang sifatnya teologi, syariat, maupun sosiologi, 2). Mereka hanya ingin mempertahankan keutuhan tradisi agar tidak terkontaminasi oleh produk luar yang di nilai merubah struktur sosial yang ada, 3). Risalah kenabian dinilai menjadi sumber perpecahan masyarakat. Hal demikian yang dirasa menjadi alasan kuat penolakan risalah kenabian, padahal hakikat misi dari para utusan adalah adanya transformasi menuju masyarakat madani.

\section{Relevansi Alasan Penolakan Masyarakat Atas Reformasi Hukum Keluarga Islam Dengan Penolakan Risalah Kenabian}

Seperti apa yang telah dibahas sebelumnya, bahwasanya alasan menolakan terhadap reformasi hukum keluaga Islam lebih mendominasi, demikian sangat dipengaruhi setidaknya tiga faktor utama, yaitu;

Pertama, Reformasi hukum keluarga Islam tidak sesuai dengan pandangan filosofis dan sosiologis yang telah mengakar dan mendalam, karena pemikiran mereka telah terdoktrin oleh fikih konservatif seperti yang dianut oleh masyarakat Afganistan,

Kedua, Metodologi pembuatan reformasi hukum keluarga Islam tidak sesuai dengan metode fikih klasik, seperti penolakan masyarakat Pakistan karena menilai golongan progresif tidak mengetahui ajaran Islam secara mendalam, dan juga telah menyeleweng dari syariat Islam karena banyak corak pikiran barat yang dibawa ke rencana perundangan tersebut,

Ketiga, reformasi hukum Islam terdapat indikasi manganulir hukum adat dan Islam, hal demikian yang menjadi salah satu alasan masyarakat Indonesia menolak unifikasi pembaruan hukum keluarga seperti rencana aturan batas minimal boleh nikah, larangan poligami, pencatatan perkawinan, talak di luar pengadilan, dan lain-lain.

Dari ketiga faktor diatas, inti alasan penolakan masyarakat terhadap reformasi hukum keluarga adalah karena ketidakmauan ideas movement (perubahan pandangan hidup), mereka lebih condong 
kepada sikap antipati terhadap perubahan dan lebih memilih hal-hal yang telah mapan.

Sementara itu, pola alasan masyarakat menolak risalah kenabian, yaitu; 1) Ketidakmauan masyarakat untuk mengalami berubahan, baik yang sifatnya teologi, syariat, maupun sosiologi, 2) Mereka hanya ingin mempertahankan keutuhan tradisi agar tidak terkontaminasi oleh produk luar yang di nilai merubah struktur sosial yang ada, 3) Risalah kenabian dinilai omong kosong karena diucapkan oleh seseorang manusia biasa yang juga menjadi sumber perpecahan masyarakat.

Dengan demikian yang dirasa menjadi titik temu penolakan risalah kenabian dan penolakan terhadap reformasi hukum keluarga adalah masyarakat menolak transformasi menuju masyarakat madani. Lebih lanjut keduanya menolak berubah dan ingin mempertahankan apa yang telah mereka kerjakan.

Selain itu juga, masyarakat juga tidak mau bersikap ideas movement, mereka tidak paham bahwa hakikat dari risalah kenabian adalah membawa misi reformormasi sosial demi terciptanya struktur masyarakat yang baik, sejahtera, damai, dan bahagia dunia dan akhirat. Masyarakat juga tidak memahami bahwasanya reformasi hukum keluarga juga merupakan buah hasil dari pemikiran para mujtahid terhadap teks wahyu, yaitu al-Qur'an dan hadis. Hanya saja mereka menginterpretasikan nash-nash tersebut sesuai dengan konteks sekarang, atau juga menggunakan metode kombinasi tematikholistik ${ }^{49}$ sebagai metode reformasi hukum keluarga Islam.

Masyarakat juga belum memahami bahwa posisi perundangundangan hukum keluarga juga sepadan dengan fikih atau bahkan lebih otoritatif dari pada fikih tradisional (konservatif) yang mereka sebut sebagai hukum Islam. Sebab perundang-undangan tersebut merupakan hasil ijtihad dan ijma' kolektif yang banyak sekali ahli-ahli yang terlibat dalam pembentukan reformasi hukum keluarga.

Tugas para Rasul adalah memberikan pemahaman kepada umatnya mengenai kebenaran ajaran yang mereka bawa serta mencerahkan dan mencerdaskan umat. Fakta empirisnya, tidak sedikit

\footnotetext{
${ }^{49}$ Khoiruddin Nasution, Hukum Perdata (Keluarga) Islam Indonesia Dan Perbandingan Hukum Perkawinan di Dunia Islam dengan Pendekatan Integratif Interkonektif, (Yogyakarta: Academia+Tazzafa, 2013), 217
} 
Rasul yang berhasil, tetapi tidak sedikit juga yang gagal. Relevansinya dengan reformasi hukum Islam adalah bahwasanya tugas para akademisi, pemerintah, pegiat adalah layaknya utusan yang membawa risalahnya. Yaitu mensosialisasikan, mempublikasikan, serta memahamkan masyarakat bahwasanya hukum keluarga merupakan aturan yang harus dipatuhi dan dijalankan sebagaimana mestinya. Karena hakikatnya hukum keluarga Islam merupakan manifestasi dari fikih, yang pada akhirnya masyarakat mau menerima dan melaksanakan aturan-aturan tersebut.

\section{Penutup}

Dengan apa yang telah dijelaskan, bahwasanya inti alasan penolakan masyarakat terhadap reformasi keluarga Islam pada negara Afganistan, Pakistan, dan Indonesia adalah karena ketidakmauan ideas movement (perubahan pandangan hidup), mereka lebih condong kepada sikap antipati terhadap ideas movement, dan lebih memilih halhal yang telah mereka lakukan. Disamping itu, masyarakat juga tidak mengetahui hikmah dan tujuan pembaharuan hukum keluarga. Sama halnya dengan umat yang menolak risalah kenabian mereka menolak adanya transformasi menuju masyarakat madani. Relevansi yang ditemukan dari kedua pembahasan tersebut adalah keduanya menolak adanya reformasi dan ingin mempertahankan nilai kemapanan. Lebih lanjut mereka sama-sama tidak paham nilai-nilai perubahan tersebut. Masyarakat konservatif yang menolak reformasi hukum keluarga tidak memahami tujuan-tujuan perubahan. Sebab itu tugas praktisi, akademisi adalah mensosialisasikan, dan mempublikasikan tujuan dan maksud reformasi hukum keluarga Islam. Sama halnya dengan tugas yang diemban oleh para Rasul, yaitu berupaya memahamkan kebenaran ajaran yang mereka bawa serta mencerahkan, mencerdaskan bangsa.

\section{Daftar Pustaka}

Al-Buthi, Muhammad Sa'id Ramadhan, Figh As-Sirah, Terj. Aunur Rafiq Shaleh Tahmid, (Jakarta: Robbani, 2002)

Al-Mahalli, Jalaluddin, dan Jalaluddin Abdur Rahman asy-Syuyuti, Tafsir al-Jalalaini, (Surabaya: Darul Jawahir, 2013)

Arief, Barmawi, "Respon Masyarakat Terhadap Hukum Keluarga Islam" , Jurnal Hukumah, Vol. 01, No. 01, (Desember, 2017) 
Badruzzaman, Abad, "Potret Kaum Perempuan Pra-Islam Dalam AlQur'an" Jurnal QOF, Vol. 3, No. 2, (Juli, 2019)

Dudi S, Asep, “Misi Risalah Islam Landasan Epistimologis Reformasi Sosial Menuju Masyarakat Madani", Makalah, LKTI Dosen Unisba Tahun 1999-2000.

Hermawati, Nety, "Respon Terhadap Hukum Perkawinan”, Jurnal AlMizan, Vol. 11 No. 1, (1 Juni, 2015)

L Esposito, John dan John J. Donohue, Islam dan Pembaharuan Ensiklopedi MasalahMasalah, (Jakarta: Rajawali, 1994)

Mubarok, Nafi', "Sejarah Hukum Perkawinan Islam Di Indonesia", Jurnal Al-Hukama, Vol. 02, No. 02, (Desember, 2012)

Mudzhar, Atho' dan Khairuddin Nasution, Hukum Keluarga di Dunia Islam Modern, Studi Perbandingan UU Modern dari Kitab-kitab Fikih, (Jakarta : Ciputat, 2003)

Mulyawan, Fitri, Kiki Yulinda, dan Dora Tiara, "Politik Hukum Dalam Bidang Hukum Keluarga Islam di Indonesia", Jurnal Ensiklopedia Social Review, Vol. 3 No. 2, (Juni, 2021)

Muslim, Abu Husain, Shahih Muslim (Beirut: Dar Ihya' al-Kutub al'Arabiyyah, $1431 \mathrm{H}$ )

Nasution, Khoiruddin, "Penolakan Umat Terhadap Risalah Kenabian Dan Relevansinya Dengan Penolakan Muslim Terhadap Undang-Undang Perkawinan," Jurnal ADHKI: Journal of Islamic Family Law, Vol. 2, No.2, (Juni, 2020)

Nasution, Khoiruddin, Hukum Perdata (Keluarga) Islam Indonesia Dan Perbandingan Hukum Perkawinan Di Dunia Islam Dengan Pendekatan Integratif Interkonektif, (Yogyakarta: Academia + Tazzafa, 2013)

Nasution, Khoiruddin, Pengantar dan Pemikiran Hukum Keluarga (Perdata) Islam Indonesia, (Yogyakarta: Academia+Tazzafa, 2010)

The Muslim Family Laws Ordinance Pakistan, 1961

Tholabi Kharlie, Ahmad dkk, Kodifikasi Hukum Keluarga Islam Kontemporer (Pembaruan, pendekatan, dan Elastisitas Penerapan Hukum, (Jakarta: Kencana, 2020)

Tim Kementerian Perwakafan dan Urusan Keislaman, al-Maus $\hat{u}^{\prime} a h$ alFiqhiyyah al-Kuwaitiyyah, cet.2, jilid 41 (Dar al-Salasil: Kuwait, $1427 \mathrm{H})$ 
Toisuta ,Hasballah. "Hukum Keluarga di Afghanistan”, Jurnal Tahkim, Vol. IX, No. 1, (Juni, 2013)

Zamroni, M. Prinsip-Prinsip Hukum Pencatatan Perkawinan di Indonesia, (Surabaya: Media Sahabat Cendikia: 2018)

Website :

BBC Indonesia, Kontroversi UU di Afganistan, http://www.bbc.co.uk/indonesian/news/story/2009/08/p rintable/090816_afghanwomen.shtml, (diakses pada tanggal 12 Maret 2021).

Kompas, UU Perkawinan Afganistan Timbulkan Pro-Kontra: https:/ travel.kompas.com/read/2009/04/15/17461321/sit emap.html, (diakses pada tanggal 12 Maret 2021).

VOA, PBB: Hak-Hak Perempuan Dilanggar di Afghanistan, https://www.voaindonesia.com/a/pbb-hak-hakperempuan-dilanggar-di-afghanistan-111638384/87095.html, (diakses pada 12 Maret 2021) 